Reprod. Nutr. Dévelop., 1984, 24 (4), 431-438.

\title{
A study of nitrogen excretion and oxygen consumption in five half-sib families of rainbow trout
}

\author{
S. J. KAUSHIK, B. FAUCONNEAU, J. M. BLANC $(*)$
}

with the technical collaboration of Denise BLANC

Laboratoire de Nutrition des Poissons, I.N.R.A.,

(*) Laboratoire d'Ecologie des Poissons et d'Aménagement des Pêches, I.N.R.A., Saint-Pée-sur-Nivelle, 64310 Ascain, France.

Summary. Branchial and urinary nitrogen (ammonia and urea) excretion and oxygen consumption rates were measured in five half-sib families of rainbow trout showing different growth rates. Ammonia loss through the gills represented the major part of nitrogen excretion and was highly correlated to nitrogen intake (NI). The fish of families 1 and 2 with better growth rates and food conversion ratios excreted much less nitrogen $(51$ and $59 \%$ of $\mathrm{NI}$, respectively) than the other 3 families (58 to $75 \%$ of NI). Urea excretion and oxygen consumption rates varied but showed no definite relation to the growth rates of the families. Biochemical utilization of dietary proteins seemed to vary in rainbow trout, and further research along these lines is required.

\section{Introduction.}

The quantification of nitrogenous waste products of fish has of late gained interest due to both the increased awareness of water quality in intensive fish culture and the fact that any effort towards the optimization of dietary protein conversion into fish body protein necessitates a precise evaluation of the magnitude of nitrogenous metabolic wastes.

As both biotic and abiotic factors affect trophic relationships through their immediate effects on the nutritional status of an organism, the influence of such factors on nitrogen excretion have been looked into in many fish species. Both daily patterns and rates of nitrogen excretion in salmonids (Brett and Zala, 1975 ; Kaushik, 1980) have also been studied in relation to nitrogen intake levels. Of other biotic factors, only the influence of age or size has been considered in some detail with respect to endogenous nitrogen excretion (Brett and Zala, 1975) and nitrogen balance (Fischer, 1976 ; Kaushik and Dabrowski, 1983).

To our knowledge, the influence of genetic differences on nitrogen utilization has not yet been studied. As individual (mass) selection for the improvement of fish growth rate is widely used, several studies have already been carried out to determine differences in carbohydrate utilization (Edwards et al., 1977 ; Austreng et al., 1977 ; Refstie and Austreng, 1981), body composition (Ayles et al., 1979) and food conversion efficiency (Kinghorn, 1983). Selection for the improvement of carbohydrate utilization or food conversion has been found to have little 
practical value. The present study was initiated as a preliminary attempt to observe possible genetic effects on nitrogen and energy metabolism in rainbow trout.

\section{Material and methods.}

a) Fish. - The rainbow trout (Salmo gairdneri Richardson) used in these trials were drawn from a pool of 25 different half-sib families. Five of these families were chosen for our experiments on the basis of their growth observed during a progeny test in the presence of " golden " phenotype controls (see Blanc et al., 1983) : fast growth (families 1 and 2), intermediate growth (families 3 and 4), slow growth (family 5).

b) Growth. - The growth of the rainbow trout was followed under different experimental conditions during three distinct periods. During the initial progeny test period of 100 days (March 18-June 30), the growth of all the families was followed at our experimental facilities at St-Pée-sur-Nivelle (fig. 1, period A). Thereafter, all the families were marked by cold-branding and then transferred to our experimental hatchery $\left(18^{\circ} \mathrm{C}\right)$ at Donzacq (Landes, 40, France) where their further growth was followed (periods $\mathrm{B}$ and $\mathrm{C}$ ).

All families were fed a commercial diet of the following chemical composition (per $\mathrm{kg}$ dry matter) : protein $(\mathrm{N} \times 6.25) 450 \mathrm{~g}$, fat $70 \mathrm{~g}$ and energy $17.97 \mathrm{MJ}$. For

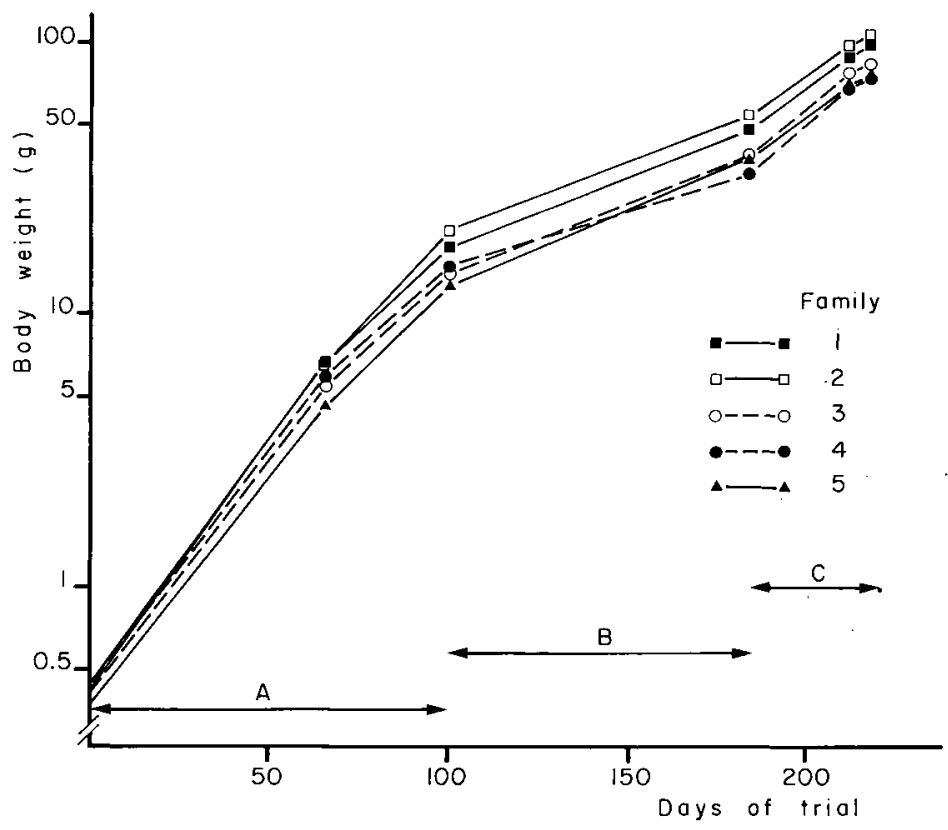

FIG. 1. -- Growth of the five different families of rainbow trout :

A) during progeny-test period (in presence of control " golden " fish); B) after transfer to hatchery (1 meal a day) ; C) during controlled growth trial of isolated groups (2 meals a day). 
the first 3 months after transfer to the hatchery, the families were mixed, fed once a day and growth was noted (fig. 1, B). A controlled growth experiment was then carried out (fig. $1 \mathrm{C}$ ) when the 5 families were separated and were fed two meals a day (9 a.m. and 4 p.m.) ad libitum.

c) Metabolism trials. - Ten fish from each family were brought to the laboratory for trials on nitrogen excretion and oxygen consumption. They were kept in cylindrical tanks (volume : $60 \mathrm{I})$ with a conical bottom. The inflow rate of the recirculated, temperature-controlled $\left(18+1^{\circ} \mathrm{C}\right)$ water was kept more or less constant (1.5 to $\left.21 \mathrm{~min}^{-1}\right)$ during the studies. Nitrogen intake (NI) was recorded daily.

Branchial excretion. - Aliquots of water samples leaving the fish tanks (flow-through system : see Kaushik, 1980) were continuously drawn throughout each 24 -h cycle using a peristaltic pump (Gilson). Collected water samples were kept cold $\left(4{ }^{\circ} \mathrm{C}\right)$ until analysis.

Urinary excretion. - The trout were kept individually in small plastic tanks (3-1 capacity) with free-flowing water. 24-h urine samples from individual catheterized fish were collected, acidified with $\mathrm{HCl}$ and stored at $4{ }^{\circ} \mathrm{C}$ until analysis.

Oxygen consumption. - Oxygen levels in the inflowing water and at the outlet of the fish tanks were measured at 2 to 3 - $h$ intervals using a portable electrode (Ponselle, France).

d) Analytical methods. - The ammonia and urea- $\mathrm{N}$ in water and urine samples were measured using the slightly modified procedures of Le Corre and Treguer (1976) and of Aminot and Kerouel (1981), respectively. Results on nitrogen excretion and oxygen consumption were expressed in $\mathrm{mg} \cdot \mathrm{kg} \mathrm{BW} W^{-1} \cdot \mathrm{d}^{-1}$.

\section{Results.}

\section{a) Growth.}

The growth of the five families when in competition with other families was slightly affected, as shown in figure 1 (period B). This was especially true for family 4. However, during the controlled growth trial when the families were raised in separate compartments, family 4 showed some recovery growth as exemplified by the slightly increased specific growth rate (SGR : 2.44). During this controlled growth trial, the SGR of the five families varied (table 1), but the individual daily weight gains of families 1 and 2 were significantly higher than those of the other three groups. Families 3 and 4 had intermediate weight gains as could be expected from observations during the early developmental period, and family 5 showed the lowest gain. Food conversion ratios (FCR) were best in families 1 and 2 (1.32 and 1.35, respectively), while the other three families showed no difference (FCR : 1.45-1.50).

b) Nitrogen excretion (table 2).

Urinary excretion. - The excretion of nitrogenous catabolites in urine was very low in comparison with the amount of nitrogen excreted through the gills 
TABLE 1

Growth and food conversion of rainbow trout of different families under controlled hatchery conditions

\begin{tabular}{lrrrrr}
\hline \multicolumn{1}{c}{ Family } & \multicolumn{1}{c}{} & \multicolumn{1}{c}{2} & \multicolumn{1}{c}{3} & 4 & \multicolumn{1}{c}{5} \\
\hline Mean Initial Weight $(\mathrm{g})$ & 45.30 & 50.65 & 37.70 & 32.10 & 35.50 \\
Final Weight $(\mathrm{g})$ & 97.10 & 100.00 & 79.70 & 71.90 & 71.00 \\
Weight gain $(\mathrm{g} / \mathrm{d})$ & 1.57 & 1.50 & 1.27 & 1.20 & 1.08 \\
SGR $(\% / \mathrm{d})(*)$ & 2.31 & 2.06 & 2.27 & 2.44 & 2.10 \\
Food intake $(\mathrm{g} / \mathrm{d})$ & 2.08 & 1.85 & 1.90 & 1.79 & 1.56 \\
FCR & $1 . * *)$ & 1.24 & 1.49 & 1.50 & 1.45 \\
\hline
\end{tabular}

(*) SGR : Specific growth rate : $100 \times \frac{\log _{e} W_{f}-\log _{e} W_{i}}{t}-$ where $W_{f}$ and $W_{i}$ are final and initial weights and $t$ the number of days.

$\left({ }^{* *}\right)$ FCR : Food conversion ratio.

TABLE 2

Urinary and branchial nitrogen excretion and oxygen consumption rates $\left({ }^{*}\right)$ in different families of rainbow trout $\left({ }^{* *}\right)$

\begin{tabular}{|c|c|c|c|c|c|c|c|c|c|c|}
\hline Family & 1 & 1 & & 2 & 3 & & 4 & & & 5 \\
\hline $\begin{array}{l}\text { Urinary Urea-N } \\
\text { Urinary }\end{array}$ & $3.21 \pm$ & $\pm \quad 0.49$ & $1.05 \pm$ & $\pm \quad 0.17$ & $3.32 \pm$ & 0.81 & $1.34 \pm$ & $\pm \quad 0.24$ & $1.59 \pm$ & 0.51 \\
\hline $\begin{array}{l}\text { Ammonia - } \mathrm{N} \\
\text { Branchial }\end{array}$ & $8.75 \pm$ & $\pm \quad 1.16$ & $4.38 \pm$ & $\pm \quad 0.64$ & $5.81 \pm$ & 1.03 & $4.34 \pm$ & $\pm \quad 0.71$ & $5.15 \pm$ & 1.92 \\
\hline $\begin{array}{r}\text { Urea-N } \\
\text { Branchial }\end{array}$ & $165 \pm$ & \pm 32 & 195 & \pm 26 & 370 & 32 & 266 & \pm 49 & $332 \pm$ & $45(* * *)$ \\
\hline $\begin{array}{l}\text { Ammonia- } \mathrm{N} \\
\text { Oxygen }\end{array}$ & 817 & \pm 116 & 674 & \pm 112 & 920 & 197 & 1,341 & \pm 259 & $922 \pm$ & 197 \\
\hline $\begin{array}{l}\text { Consumption } \\
\mathrm{N} \text { excreted as }\end{array}$ & $10.58 \pm$ & $\pm \quad 2.22$ & $9.45 \pm$ & $\pm \quad 1.68$ & $14.45 \pm$ & 5.88 & $14.50 \pm$ & $\pm \quad 3.54$ & $11.08 \pm$ & 3.83 \\
\hline $\begin{array}{l}\% \text { of } N \text {-intake } \\
\text { A:U ratio }\left(^{* * * *}\right) \\
O: N \text { ratio }\end{array}$ & $\begin{array}{r}51.33 \pm \\
5.00 \pm\end{array}$ & $\begin{array}{l}\mathbf{9} 9.30 \\
\pm \quad 0.48\end{array}$ & $\begin{array}{r}59.00 \pm \\
3.49 \pm\end{array}$ & $\begin{array}{l} \pm \quad 9.17 \\
\pm \quad 0.71\end{array}$ & $\begin{array}{r}74.75 \pm \\
2.52 \pm\end{array}$ & $\begin{array}{l}8.79 \\
0.66\end{array}$ & $\begin{array}{r}61.37 \pm \\
5.24 \pm\end{array}$ & $\begin{array}{l}\quad 6.62 \\
\pm \quad 1.57\end{array}$ & $\begin{array}{r}57.50 \pm \\
3.26 \pm\end{array}$ & $\begin{array}{l}7.12 \\
0.56\end{array}$ \\
\hline$(* * * *)$ & $10.76 \pm$ & $\pm \quad 1.57$ & $10.94 \pm$ & $\pm \quad 1.81$ & $11.26 \pm$ & 4.51 & $9.37 \pm$ & $\begin{array}{l}+3.45 \\
\pm\end{array}$ & $8.84 \pm$ & 3.17 \\
\hline
\end{tabular}

$\left(^{*}\right)$ Nitrogen excretion and oxygen consumption expressed in $\mathrm{mg} \mathrm{N} . \mathrm{Kg} \mathrm{BW}^{-1} \cdot \mathrm{d}^{-1}$ and g O $2 . \mathrm{Kg}$ $B W^{-1} \cdot d^{-1}$ respectively ; (**) Mean and standard deviation are given $(n=7) ;\left({ }^{* *}\right)$ Mean and S.D. of 4 values only; $\left({ }^{* * *}\right)$ Ratio between excreted ammonia $\mathrm{N}$ and urea $\mathrm{N} ;\left({ }^{* * * *}\right)$ Ratio between $\mathrm{O}_{2}$ consumption and $\mathrm{N}$ excretion.

(table 2). Much variability was observed in urinary loss of both urea and ammonia. Family 1 fish showed a significantly higher urinary excretion rate than fish of other families, but the relative proportion of urea to ammonia excreted in urine was much higher in family 3.

Branchial excretion. - Significant differences were observed both in the total amount of nitrogen excreted across the gills and in the relative proportions of the two catabolites (urea and ammonia) analyzed. The trout of families 1 and 2 excreted much less nitrogen than the other families. Expressed in terms of NI, fish of families 1, 2 and 5 lost between 51 and $59 \%$ of NI compared to families 3 and 
4 which excreted more (61 to $75 \%$ of NI). Relatively more ammonia in comparison to urea was excreted by families 1 and 4 (5 times more ammonia), while in family 3 the ammonia : urea ratio was lower (2.5).

c) Oxygen consumption.

Two of the five families (families 3 and 4) showed significantly higher oxygen consumption rates $\left(14.5 \mathrm{~g} \mathrm{O}_{2} . \mathrm{Kg} \mathrm{BW}^{-1} . \mathrm{d}^{-1}\right)$ than the others 19.5 to $11 \mathrm{~g} \mathrm{O}_{2} \cdot \mathrm{Kg} \mathrm{BW}^{-1} \cdot \mathrm{d}^{-1}$ ). The $\mathrm{O}: \mathrm{N}$ ratios (ratio between oxygen consumption and nitrogen excretion rates) were variable, mean values ranging between 8.8 and 11.3 .

The matrix of correlations between the different parameters is presented in table 3. As the number of families tested was small, with only 3 degrees of freedom, the conclusions would be of limited validity. However, the relation between nitrogen intake and branchial ammonia excretion was significant $(r=0.91)$.

\section{Discussion.}

The high correlation between $\mathrm{N}$-intake and branchial ammonia excretion is a well-documented phenomenon. As $\mathrm{N}$-intakes were variable and as ENE was not measured, no clear-cut differences in basal metabolism among these fish could be demonstrated; differences in oxygen uptake rates were not significant either. Urea excretion rates were more variable than ammonia excretion rates. No effect of dietary $\mathrm{N}$-intake on urea excretion rate was observed, as has already been noted in salmonids (Brett and Zala, 1975).

In teleosts, the major part (50 to $80 \%$ ) of total nitrogen excreted is in the form of ammonia, and about 5 to $15 \%$ is accounted for by urea nitrogen (Smith, 1929 ; Vellas and Serfaty, 1974). The gills are the main excretory organs. The volume of urine excreted and its composition are variable depending on the species, its nutritional status and environmental condition (Watts and Watts, 1974). Other forms of nitrogenous end-products like creatine, creatinine and free amino acids are also excreted by teleosts (Smith, 1929 ; Wood, 1958 ; Ogata et al., 1983). In drawing nitrogen budgets, although total nitrogen excretion must be

TABLE 3

Correlation matrix of metabolic data based on family means

\begin{tabular}{|c|c|c|c|c|c|}
\hline & \multicolumn{2}{|c|}{ Urinary } & \multicolumn{2}{|c|}{ Branchial } & \multirow[b]{2}{*}{$\mathrm{O}_{2}$ uptake } \\
\hline & Urea & Ammonia & Urea & Ammonia & \\
\hline Urinary Ammonia & 0.792 & & & & \\
\hline Branchial Urea & 0.150 & -0.376 & & & \\
\hline Branchial Ammonia & -0.164 & -0.312 & 0.321 & & \\
\hline $\mathrm{O}_{2}$ uptake & 0.267 & -0.212 & 0.638 & 0.788 & \\
\hline $\mathrm{N}$ intake & -0.224 & -0.153 & 0.174 & 0.911 & 0.523 \\
\hline
\end{tabular}

Significant levels at 3 degrees of freedom : 0.805 at $10 \%, 0.878$ at $5 \%$ and 0.959 at $1 \%$. 
considered, a relatively precise approximation can however be obtained by measuring only the two major nitrogenous catabolites.

The origin of ammonia in teleosts is considered as due to both transdeamination and the adenosine monophosphate (AMP) deaminase cycle, the former being slightly predominant (Walton and Cowey, 1982). Not all of the ammonia produced is excreted ; it is converted to glutamine by the action of glutamine synthetase in several teleost tissues (Wu, 1963 ; Pequin et al., 1970). As regards the conversion of part of the ammonia for carbamoyl phosphate synthesis (Watts and Watts, 1974), conclusive evidence on the origin, level and activity of the key enzyme, carbamoyl phosphate synthetase (CPS), is lacking in fish (see Dabrowski and Kaushik, 1982).

Ureagenesis in fish also appears to be under the control of three different pathways: the urea cycle, purine breakdown and arginine degradation. A full complement of the ornithine-urea cycle (OUC) enzymes has been detected in many teleosts; but their levels and activities appear variable (Huggins et al., 1969 ; Wilson, 1973). According to Dépêche et al. (1979), OUC is operative only in the embryos of rainbow trout and not in other stages. Purine breakdown appears to be the main urea-forming pathway in carp (Vellas and Serfaty, 1974). Ureagenesis due to arginine breakdown still remains an issue, as the quantitative dietary requirement of teleosts for this essential amino acids is controversial.

Although an increase in urinary $\mathrm{N}$-excretion would lead to a greater energy demand than would an increase in branchial excretion, which involves passive evacuation of nitrogenous wastes, the oxygen consumption rates do not reflect any such effect. Since practically all metabolic wastes are diffused across the gills, variations in urinary $\mathrm{N}$-excretion rates, if any, are too small to affect oxygen consumption levels. The very low amount of nitrogen (ammonia + urea) in the urine of trout, as documented here, was probably mostly due to the fact that other forms of nitrogenous waste are also present in teleost urine (Ogata et al., 1983).

Of the five groups, families 1 and 3 were quite distinct from each other, both in terms of metabolic $\mathrm{N}$-loss and growth performance. The ammonia : urea ratio was also twofold higher in the former family. The higher oxygen consumption rate in family 3 probably reflects the increase in energy demand associated with increased urea excretion (table 2). Whatever the pathway of ureagenesis, both synthesis and excretion of urea are more energy-demanding processes than ammonia formation and excretion (see Smith et al., 1978).

Trout belonging to families 1 and 2 showed better retention of ingested nitrogen as was also reflected by better FCR and growth than those of the other three families. Families with intermediate growth (families 3 and 4) showed greater N-loss and poor FCR. On the contrary, family 5 did not show such a distinct relation between FCR and $\mathrm{N}$-excretion; some interaction with energy metabolism was probably involved, as indicated by the low $\mathrm{O}: \mathrm{N}$ ratio. Daily food intake was also low in this group.

Only little or variable success has been recorded in mass selection of fish for improved growth rate (Moav, 1979). According to Chevassus (1982), this is due to several reasons, a lack of within-tank control (e.g. use of « golden » strains) and 
social interactions being the major ones. It may also be attributed to the notion of growth or production of fish in terms of caloric units, rather than as a maximization of the production of useful materials such as protein (Weatherley, 1976). A finer distinction between the satisfactory growth rate of fish and their ability to sustain such growth is also required.

The results presented here are only preliminary observations on differences in response to nitrogen intake. Although a distinct genetic effect cannot be demonstrated, studies of this kind need further attention as there is some indication that the biochemical utilization of dietary proteins varies among different families of rainbow trout, as shown by Austreng and Refstie (1979). Torrissen and Torrissen (1984) likewise found some differences in protease activity in the digestive tract of five strains of Atlantic salmon.

Recu en octobre 1983.

Accepté en mars 1984.

Résumé. Etude de l'excrétion azotée et de la consommation d'oxygène chez cinq familles de Truite arc-en-ciel.

L'excrétion branchiale et urinaire (ammoniaque + urée) et la consommation d'oxygène ont été mesurées chez les truites arc-en-ciel appartenant à cinq familles de demi-frères. Les familles ont été choisies en fonction de leur croissance : familles 1 et 2 à forte croissance, 3 et 4 avec une croissance moyenne et famille 5 ayant une croissance moindre. L'excrétion ammoniacale branchiale représente la majeure partie de l'azote excrétée et est significativement liée à la consommation azotée. Les familles 1 et 2 ont enregistré une meilleure efficacité alimentaire (Indice de Consommation de 1,32 et 1,25 respectivement) par rapport aux poissons des autres familles (IC de 1,45 à 1,50). L'excrétion azotée en fonction de l'ingérée est également inférieure chez les truites de ces deux 'amilles (51 et $59 \%$ de l'ingérée chez les familles 1 et 2 respectivement) comparée à celles observées chez les autres groupes. L'excrétion uréique (urinaire ou branchiale) et la consommation d'oxygène ne reflètent pas de telles variations. II existe une certaine variabilité entre différentes familles de Truite arcen-ciel en ce qui concerne l'utilisation métabolique de l'azote ingérée.

\section{References}

AMINOT A., KEROUEL R., 1982. Dosage automatique de l'urée dans l'eau de mer : une méthode très sensible à la diacétyl monoxime. Can. J. Fish. Aquat. Sci., 39, 174-183.

AUSTRENG E., REFSTIE T., 1979. Effect of varying dietary protein level in different families of rainbow trout. Aquaculture, 18, 145-156.

AUSTRENG E., RISA S., EDWARDS D. J., HVIDSTEN H., 1977. Carbohydrate in rainbow trout diets. II. Influence of carbohydrate levels on chemical composition and feed utilization of fish from different families. Aquaculture, 11, 39-50.

AYLES G. B., BERNARD D., HENDZEL M., 1979. Genetic differences in lipid and dry matter content between strains of rainbow trout (Salmo gairdneri) and their hybrids. Aquaculture, 18, 253-262.

BLANC J. M., CHEVASSUS B., POISSON H., 1983. Utilization de mutants "Golden " comme témoins intra-lots pour le testage des performances de croissance chez la Truite arc-en-ciel. Cybium, 7, 93-103.

BRETT J. R., ZALA C. A., 1975. Daily pattern of nitrogen excretion and oxygen consumption of sockeye salmon (Oncorhynchus nerka) under controlled conditions. J. Fish. Res. Board Can., 32, 2479-2486. 
CHEVASSUS B., 1982. Facteurs génétiques et sociaux influençant la croissance chez les poissons. Oceanis, 8, 493-609.

DABROWSKI K., KAUSHIK S. J., 1982. The concept of pyrimidine essentiality in fish. Spec. Sci. Tech., 5, 447-454.

DÉPECCHE J., GILLES R., DAUFRESNE S., CHIAPELLO H., 1979. Urea content and urea production via the ornithine urea cycle pathway during the ontogenic development of two teleost fishes. Comp. Biochem. Physiol., 63 A, 51-56.

EDWARDS D. J., AUSTRENG E., RISA S., GJEDREM T., 1977. Carbohydrate in rainbow trout diets. I. Growth of fish of different families fed diets containing different proportions of carbohydrate. Aquaculture, 11, 31-38.

FISHER Z., 1976. Nitrogen conversion in carp (Cyprinus carpio L.). Pol. Arch. Hydrobiol., 23, 309-326.

HUGGINS A. K., SKUTSCH G., BALDWIN E., 1969. Ornithine-urea cycle enzymes in teleost fish. Comp. Biochem. Physiol., 28, 587-602.

KAUSHIK S. J., 1980. Influence of nutritional status on the daily patterns of nitrogen excretion in the carp (Cyprinus carpio L.) and the rainbow trout (Salmo gairdneri R.). Reprod. Nutr. Dévelop., 20, 1751-1765.

KAUSHIK S. J., DABROWSKI K., 1983. Nitrogen and energy utilization in juvenile carp (Cyprinus carpio) fed casein, amino acids or a protein-free diet. Reprod. Nutr. Dévelop., 23, 741-754.

KINGHORN B., 1983. Genetic variation in food conversion efficiency and growth in rainbow trout. Aquaculture, 32, 141-155.

LE CORRE P., TREGUER P., 1976. Contribution à l'étude de la matière organique dissoute et des sels nutritifs dans l'eau de mer. Caractéristiques chimiques du Golfe de Gascogne et des Upwellings côtiers de l'Afrique du Nord-Ouest. Thèse d'Etat, Univ. Bretagne Occidentale, Brest, France, $490 \mathrm{p}$.

MOAV R., 1979. Genetic improvement in aquaculture industry, 610-622. In PILLAY T. V. R., DILL Wm., A., Advances in Aquaculture, Fishing News Books Ltd, Farham, Surrey, England.

OGATA H., MURAI T., NOSE T., 1983. Free amino acid composition in urine of carp and channel catfish. Bull. Jap. Soc. Scient. Fish., 49, 1471.

PEQUIN L., PARENT J. P., VELLAS F., 1970. Glutamate dehydrogenase in carp. Distribution and role in ammoniagenesis. Arch. Sci. Physiol., 24, 315-322.

REFSTIE T., AUSTRENG E., 1981. Carbohydrate in rainbow trout diets. III. Growth and chemical composition of fish from different families fed four levels of carbohydrate in the diet. Aquaculture, 25, 35-49.

SMITH H. W., 1929. The excretion of ammonia and urea by the gills of fish. J. biol. Chem., 82, 727-742.

SMITH R. R., RUMSEY G. L., SCOTT M. L., 1978. Heat increment associated with dietary protein, fat, carbohydrate and complete diets in salmonids : comparative energetic efficiency. $J$. Nutr., 108, 1025-1032.

TORRISSEN K. R., TORRISSEN O. J., 1984. Digestive proteases of Atlantic salmon (Salmo salar) from different river strains : development after hatching, rearing temperature effect and effect of sex and maturation. Comp. Biochem. Physiol., 77 B, 15-20.

VELLAS F., SERFATY A., 1974. Ammonia and urea in a freshwater teleost-carp. J. Physiol., Paris, 68, 591-614.

WALTON M. J., COWEY C. B., 1982. Aspects of intermediary metabolism in fish. Comp. Biochem. Physiol., 73 B, 59-79.

WATTS R. L., WATTS D. C., 1974. Nitrogen metabolism in fishes. Chem. Zool., 8, 369-446.

WEATHERLEY A. H., 1976. Factors affecting maximization of fish growth. J. Fish. Res. Board Can., 33, 1046-1058.

WILSON R. P., 1973. Nitrogen metabolism in channel catfish. II. Evidence for an apparent incomplet ornithine urea cycle. Comp. Biochem. Physiol., 46 B, 625-634.

WOOD J. D., 1958. Nitrogen excretion in some marine teleosts. Can. J. Biochem. Physiol., 36, 1237-1242.

WU C., 1963. Glutamine synthetase. I. A comparative study of its distribution in animals and its inhibition by D, L-allo- $\delta$-hydroxy-lysine. Comp. Biochem. Physiol., 8, 335-351. 